\title{
A PheWAS study of a large observational epidemiological cohort of African Americans from the REGARDS study
}

\author{
Xueyan Zhao ${ }^{1 \dagger}$, Xin Geng ${ }^{2,3+}$, Vinodh Srinivasasainagendra', Ninad Chaudhary ${ }^{4}$, Suzanne Judd ${ }^{1}$, Virginia Wadley ${ }^{5}$, \\ Orlando M. Gutiérrez ${ }^{4,5}$, Henry Wang ${ }^{6}$, Ethan M. Lange ${ }^{7}$, Leslie A. Lange ${ }^{7}$, Daniel Woo ${ }^{8}$, Frederick W. Unverzagt ${ }^{9}$, \\ Monika Safford ${ }^{10}$, Mary Cushman ${ }^{11}$, Nita Limdi ${ }^{12}$, Rakale Quarells ${ }^{13}$, Donna K. Arnett ${ }^{14}$, Marguerite R. Irvin ${ }^{4^{*}}$ and \\ Degui Zhi $\mathrm{Hi}^{3,15^{*}}$
}

From The International Conference on Intelligent Biology and Medicine (ICIBM) 2018

Los Angeles, CA, USA. 10-12 June 2018

\begin{abstract}
Background: Cardiovascular disease, diabetes, and kidney disease are among the leading causes of death and disability worldwide. However, knowledge of genetic determinants of those diseases in African Americans remains limited.

Results: In our study, associations between 4956 GWAS catalog reported SNPs and 67 traits were examined among 7726 African Americans from the REasons for Geographic and Racial Differences in Stroke (REGARDS) study, which is focused on identifying factors that increase stroke risk. The prevalent and incident phenotypes studied included inflammation, kidney traits, cardiovascular traits and cognition. Our results validated 29 known associations, of which eight associations were reported for the first time in African Americans.

Conclusion: Our cross-racial validation of GWAS findings provide additional evidence for the important roles of these loci in the disease process and may help identify genes especially important for future functional validation.
\end{abstract}

Keywords: PheWAS, African Americans, Genetics, Cardiovascular disease

\section{Background}

Genome Wide Association Studies (GWASs) have provided a powerful approach for identifying association between genetic variants and a single phenotype. An alternative and complementary approach to query genotype-phenotype associations is the Phenome-Wide Association Study (PheWAS) [1]. With PheWAS, associations between a specific genetic variant and a wide range of phenotypes can be explored. They are well suited to facilitate the identification of new associations

\footnotetext{
* Correspondence: irvinr@uab.edu; Degui.zhi@uth.tmc.edu

${ }^{+}$Xueyan Zhao and Xin Geng contributed equally to this work.

${ }^{4}$ Department of Epidemiology, University of Alabama at Birmingham, Birmingham, AL 35233, USA

${ }^{3}$ School of Biomedical Informatics, The University of Texas Health Science Center at Houston, Houston, TX 77030, USA

Full list of author information is available at the end of the article
}

between SNPs and phenotypes as well as SNPs with pleiotropy [2-4]. The PheWAS approach was mainly pioneered by investigators at Vanderbilt University [1] and flourished in various hospital-based cohorts by scanning phenomic data in electronic medical records for genetic associations $[1,4-6]$ as well as by meta-analyzing data collected in observational cohort studies like the Population Architecture using Genomics and Epidemiology (PAGE) study [2].

As of January 2017, GWASs have identified 44,000 SNPs important for various human phenotypes as summarized in the GWAS catalog [7], which makes it possible to reveal pleiotropic effects and genetic mechanisms shared by different traits. Conducting PheWASs using SNPs which were reported to be associated with one or more traits is an efficient method for replication

(c) The Author(s). 2019 Open Access This article is distributed under the terms of the Creative Commons Attribution 4.0 International License (http://creativecommons.org/licenses/by/4.0/), which permits unrestricted use, distribution, and reproduction in any medium, provided you give appropriate credit to the original author(s) and the source, provide a link to the Creative Commons license, and indicate if changes were made. The Creative Commons Public Domain Dedication waiver (http://creativecommons.org/publicdomain/zero/1.0/) applies to the data made available in this article, unless otherwise stated. 
of previous results and identification of pleiotropic effects.

In this study, we used the REasons for Geographic And Racial Differences in Stroke (REGARDS) Study to examine 4956 GWAS catalog SNPs (Additional file 1) that are included on the Infinium HumanExome-12v1-2_A (exome chip) array from Illumina with a rich collection of phenotypes. The REGARDS study is a population-based, longitudinal study including 30,000 participants ( 40\% African Americans), sampled from the continental US [8]. Among 12,000 African American participants, 7726 were genotyped with the exome chip. Since most PheWAS studies have considered individuals of European ancestry and cross-sectional phenotypes, REGARDS is an excellent resource for both cross-racial validation and identifying pleiotropic effects.

\section{Results}

We tested for association between 4956 GWAS catalog SNPs and 67 phenotypes. Genomic inflation factors $(\lambda)$ generated from including all SNPs for a given phenotype showed good fitting of all models with $\lambda$ range from 0.95 to 1.12 . Table 1 summarizes 29 significant associations passing the significance threshold with $P$ value less than

Table 1 Summary of identified significant associations in REGARDS study

\begin{tabular}{|c|c|c|c|c|c|c|c|}
\hline SNP ID & Phenotype & Minor allele (effect allele) & Major Allele & Beta or OR & P-value & MAF & First reported in AAs \\
\hline \multicolumn{8}{|c|}{ Matched phenotype } \\
\hline rs10096633 & Triglycerides & $\mathrm{T}$ & C & -0.020 & $4.88 \mathrm{E}-10$ & 0.4226 & \\
\hline rs1173727 & Height & $\mathrm{T}$ & C & 0.297 & $9.89 \mathrm{E}-08$ & 0.2032 & yes \\
\hline rs12110693 & Heart rate & G & A & -1.302 & $4.28 \mathrm{E}-11$ & 0.4984 & \\
\hline rs12740374 & LDL Cholesterol & $\mathrm{T}$ & G & -4.314 & $1.64 \mathrm{E}-10$ & 0.2615 & \\
\hline rs173539 & HDL Cholesterol & $\mathrm{T}$ & C & 2.337 & $1.21 \mathrm{E}-19$ & 0.3647 & yes \\
\hline rs1800775 & HDL Cholesterol & C & A & -2.843 & $1.53 \mathrm{E}-29$ & 0.4272 & yes \\
\hline rs247616 & HDL Cholesterol & $\mathrm{T}$ & C & 4.309 & $4.88 \mathrm{E}-52$ & 0.2528 & yes \\
\hline rs2794520 & $\mathrm{C}$ reactive protein & $\mathrm{T}$ & C & -0.125 & $3.92 \mathrm{E}-34$ & 0.2146 & \\
\hline rs326 & Triglycerides & A & G & 0.019 & $8.20 \mathrm{E}-09$ & 0.4436 & \\
\hline rs3764261 & HDL Cholesterol & A & C & 3.050 & $1.84 \mathrm{E}-30$ & 0.3165 & \\
\hline rs6511720 & LDL Cholesterol & $\mathrm{T}$ & G & -5.624 & 1.19E-10 & 0.1337 & \\
\hline rs6511720 & Total Cholesterol & $\mathrm{T}$ & G & -6.143 & $3.14 \mathrm{E}-10$ & 0.1337 & \\
\hline rs7412 & LDL Cholesterol & $\mathrm{T}$ & C & -15.870 & $2.17 \mathrm{E}-65$ & 0.1114 & \\
\hline rs7499892 & HDL Cholesterol & $\mathrm{T}$ & C & -2.351 & $1.38 \mathrm{E}-19$ & 0.3677 & yes \\
\hline rs7553007 & $\mathrm{C}$ reactive protein & $A$ & G & -0.122 & $6.61 \mathrm{E}-34$ & 0.2258 & \\
\hline rs876537 & $\mathrm{C}$ reactive protein & T & C & -0.124 & 7.99E-33 & 0.2083 & \\
\hline rs9398652 & Heart rate & C & A & -1.339 & $1.19 \mathrm{E}-11$ & 0.4956 & \\
\hline \multicolumn{8}{|c|}{ Related phenotype } \\
\hline rs12740374 & Dyslipidemia & $\mathrm{T}$ & G & 0.783 & $1.08 \mathrm{E}-10$ & 0.2615 & \\
\hline rs12740374 & Total Cholesterol & $\mathrm{T}$ & G & -4.152 & $3.24 \mathrm{E}-08$ & 0.2615 & \\
\hline rs247616 & Fram_CHD & $\mathrm{T}$ & C & -0.041 & $3.78 \mathrm{E}-09$ & 0.2528 & yes \\
\hline rs629301 & Dyslipidemia & G & $\mathrm{T}$ & 0.827 & 4.32E-08 & 0.3633 & \\
\hline rs646776 & Dyslipidemia & C & $\mathrm{T}$ & 0.827 & 4.41E-08 & 0.3622 & yes \\
\hline rs6511720 & Dyslipidemia & $\mathrm{T}$ & G & 0.737 & $4.45 \mathrm{E}-10$ & 0.1337 & \\
\hline rs 7412 & Fram_CHD & $\mathrm{T}$ & C & -0.066 & $3.03 \mathrm{E}-12$ & 0.1114 & \\
\hline rs7412 & Ideal7 & $\mathrm{T}$ & C & 0.210 & 3.35E-14 & 0.1114 & \\
\hline rs7412 & Dyslipidemia & $\mathrm{T}$ & C & 0.525 & $6.16 \mathrm{E}-33$ & 0.1114 & \\
\hline rs7412 & Total Cholesterol & $\mathrm{T}$ & C & -13.330 & $2.90 \mathrm{E}-37$ & 0.1114 & \\
\hline rs7903146 & Diabetes & $\mathrm{T}$ & C & 1.306 & $2.30 \mathrm{E}-12$ & 0.2919 & \\
\hline rs911119 & Cystatin C & C & $\mathrm{T}$ & -0.012 & $6.17 \mathrm{E}-08$ & 0.356 & yes \\
\hline
\end{tabular}

Beta coefficients were showed for continuous variables and odd ratios (OR) were showed for binary variables. MAF: minor allele frequency. Matched phenotype means the same phenotype and SNP associations have been showed in previous published studies; if similar or related associations have been published before, they are defined as "related phenotype". If this is the first time that an association was shown in Africa American population, "Yes" was given in the column" First reported in AAs" 
1.5E-7. S2 compares results extracted from the GWAS catalog on significant PheWAS SNPs to the REGARDS results. The significant associations are in several major phenotype groups: $\mathrm{C}$ reactive protein, lipid profile, diabetes, cystatin $\mathrm{C}$, heart event risk, heart rate, and height. We classified the significant SNPs in two ways: 1 . the SNP was associated to a phenotype matching previous publications 2. the SNP was associated to a phenotype related to the previously reported phenotype (Additional file 2).

\section{Validation of known genetic associations of phenotypes}

Among the 29 significant genotype and phenotype associations, 17 have been previously reported for the same phenotype (Table 1 and Additional file 2). The effect directions of the 17 associations were the same as those in the previous reports. For eight of these phenotype genotype associations, our study represents the first validation in an African American population (see section below). These replications validated the reliability of our PheWAS analysis approaches. We confirmed that $\mathrm{C}$ reactive protein level was related to rs2794520 $(P=3.9 \mathrm{E}-34)$, rs7553007 ( $P=6.6 \mathrm{E}-34)$ and rs876537 $(P=8.0 \mathrm{E}-33)$, which are located near the $C R P$ gene (Table 1). Five SNPs located near the CETP gene were associated with HDL cholesterol including rs173539 $(P=1.2 \mathrm{E}-19)$, rs1800775 $(P=1.5 \mathrm{E}-29)$, rs247616 $(P=4.9 \mathrm{E}-19), \quad$ rs3764261 $\quad(P=1.8 \mathrm{E}-30)$, and rs7499892 $(P=1.4 \mathrm{E}-19)$. Two SNPs were significantly associated with heart rate: rs12110693 near LOC644502 gene $(P=4.3 \mathrm{E}-11)$ and $\mathrm{rs} 9398652$ near GJA1 gene $(\mathrm{P}=$ 1.2E-11). We also reproduced the association between rs1173727 near the NPR3 gene and height with $P=9.9 \mathrm{E}-8$. Three SNPs were significantly associated with LDL cholesterol including rs12740374 in the SORT1/ PSRC1/ CELSR2 cluster $(P=1.6 \mathrm{E}-10)$, rs6511720 in $\operatorname{LDLR}(\mathrm{P}=$ 1.2E-10), and rs7412 in APOE ( $P=2.2 \mathrm{E}-65)$. Rs10096633 in the $L P L$ gene $(\mathrm{P}=4.9 \mathrm{E}-10)$ and rs326 in the C8orf35/ SLC18A1/LPL cluster $(P=8.2 \mathrm{E}-9)$ were associated with total cholesterol. Apart from 17 reported associations, the other 12 SNPs were associated with phenotypes that are closely related to previously published associations indexed in the GWAS catalog (Table 1 and Additional file 2).

\section{Cross-racial validation}

Eight of our findings were reported in other races previously but not in African Americans. Observed associations of rs173539, rs1800775, rs247616, and rs7499892 with HDL had not been previously reported in African Americans. The other new cross-ethnic validations from our study included rs1173727 with height, rs911119 with cystatin C, rs247616 with the Framingham risk score, and rs646776 with dyslipidemia (Table 1 and Additional file 2). Interestingly, we saw even more significant results for the association between rs247616 and HDL with $P=$ $4.88 \mathrm{E}-52$ and beta value $=4.3(\mathrm{mg} / \mathrm{dL})$ in REGARDS, compared to $P=9.7 \mathrm{E}-24$ and beta value $=3.0(\mathrm{mg} / \mathrm{dL})$ in the GWAS catalog report [9] (Additional file 2).

\section{SNPs associated with multiple traits}

The 29 significant genotype and phenotype associations involved 20 SNPs, and 11 of these were associated with multiple traits $(P$-value $<1.0 \mathrm{E}-7$ for the first trait and $P$ $<3.7 \mathrm{E}-5$ for the second trait) (Additional file 3). We also listed the genome-wide significant SNPs for one trait which were suggestively associated with another trait with nominal $P<0.05$ in Additional file 3. Figure 1 listed those 11 SNPs and another 8 SNPs which were significantly associated with the first trait $(\mathrm{P}$-value $<1.0 \mathrm{E}-7)$ and nominally associated with another trait $(\mathrm{P}<0.05)$. Generally, the pleotropic effects were caused by one SNP associated with multiple correlated phenotypes. In the conditional analysis, the associations were not significant between the second top traits and the corresponding SNPs after including the top traits as the covariate. For example, rs7412 was associated with LDL $(P=7.64 \mathrm{E}-62)$ and Cystatin $\mathrm{C}(P=1.80 \mathrm{E}-04)$ due to a significant association between these two phenotypes $(P$ $=6.48 \mathrm{E}-06)$.

\section{Discussion}

Our PheWAS presented association of 4956 SNPs with 67 phenotypes using a subset of African Americans from the REGARDS study. Our study validated 29 previous GWAS associations, of which eight associations were reported for the first time in African Americans (AAs). Among many of our findings, 11 SNPs were associated with multiple traits.

We identified 29 significant genotype and phenotype associations. 17 of these have been reported previously. The phenotypes of the other 12 associations were related with those previously reported but not exactly the same. For instance, rs911119 located in the CST3/CST4/CST9 gene cluster was reported previously associated with chronic kidney disease in a European population [10]. Our current study found that in African Americans allele $C$ of rs911119 was negatively associated with the level of cystatin $C$, which is a biomarker for kidney function $(P=6.2 \mathrm{E}-8)$. Rs7903146 in TCF7L2 gene was reported associated with type 2 diabetes in several different populations [11], which agrees with our current results $(P=2.3 \mathrm{E}-12)$. Rs247616 in the CETP gene was significantly associated with the Framingham CHD Hard Event Risk Score (Fram_CHD: Risk of Coronary Death or MI over 10 Years) with $P=3.8 \mathrm{E}-9$. While this SNP has not been previously associated with the Framingham risk score, it has been associated with its components as well as related phenotypes including blood metabolite levels, cardiovascular disease risk factors, and lipoprotein-associated phospholipase A2 mass and activity only in Europeans 


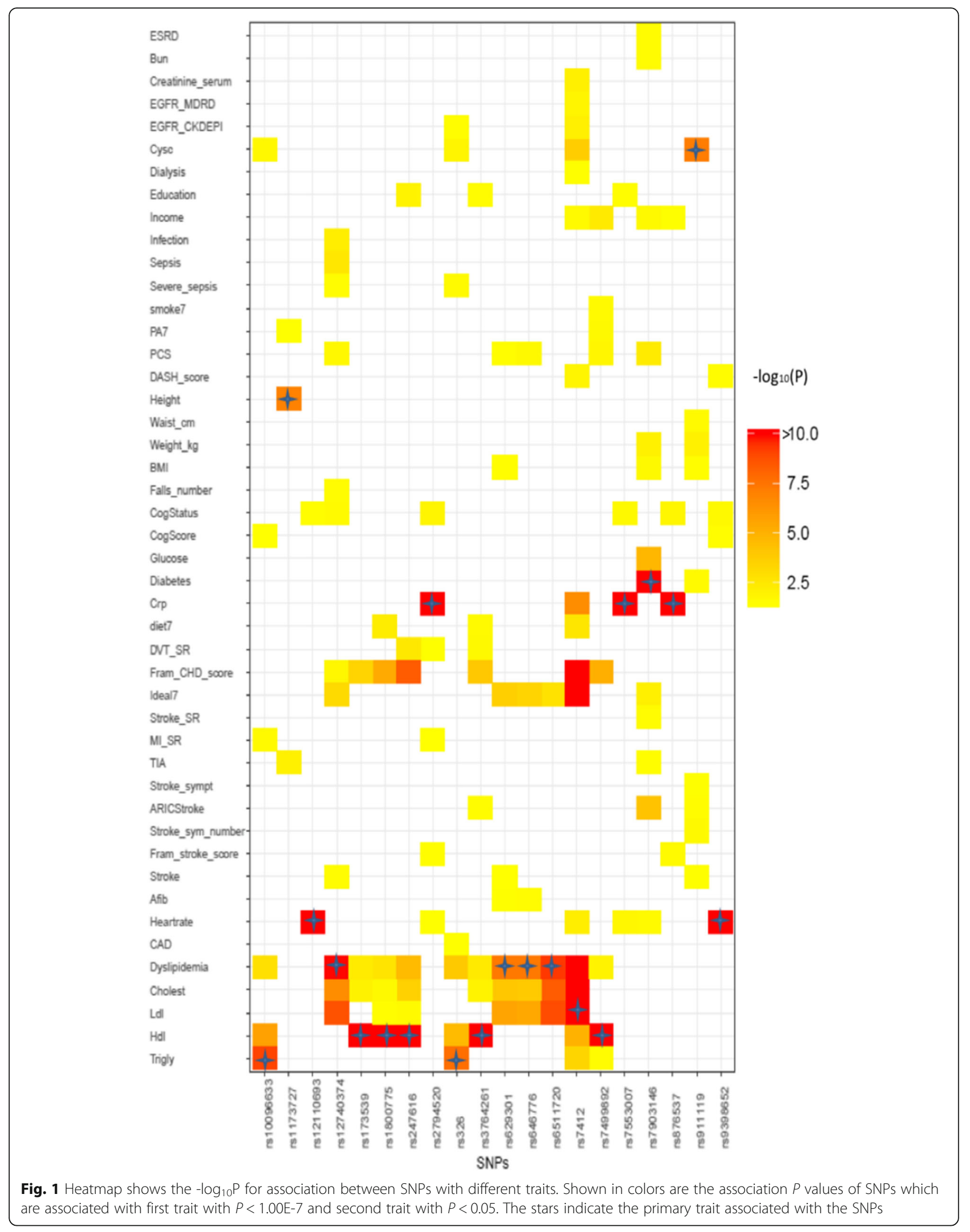


$[9,12,13]$. Rs7412 in the APOE gene was associated with Fram_CHD $(P=3.0 \mathrm{E}-12)$, total cholesterol $(P=2.9 \mathrm{E}-37)$, lipidemia $(\mathrm{P}=6.2 \mathrm{E}-33)$ and Ideal7 (the American Heart Association's "Life's Simple Seven" score, i.e., total number of ideal risk behaviors or metrics for each of the seven) ( $P$ $=3.3 \mathrm{E}-14$ ). Our findings were consistent with previous studies, which showed that rs7412 was associated with several lipid related phenotypes including LDL cholesterol, lipid metabolism phenotypes, lipid traits, and response to statin therapy [14-17]. Here, we also found that rs629301 (in CELSR2, PSRC1 and SORT1), rs646776 (in CELSR2, PSRC1 and SORT1) and rs6511720 (in LDLR) are associated with dyslipidemia. This is in alignment with previously findings: associations of rs629301 with total cholesterol and LDL cholesterol [18]; associations of rs646776 with total cholesterol, LDL cholesterol, lipid metabolism phenotypes, coronary artery disease, myocardial infarction (early onset), and response to statin therapy in Europeans [19, 20]; associations of rs6511720 with total cholesterol, LDL cholesterol, lipid metabolism phenotypes, lipoprotein-associated phospholipase A2 activity and mass, and cardiovascular disease risk factors [18]. Rs12740374 in CELSR2/PSRC1/ SORT1 cluster was associated with two lipid traits: total cholesterol and dyslipidemia in our study, which is closely related with previously reported associations with LDL cholesterol and lipoprotein-associated phospholipase A2 activity and mass $[21,22]$.

We validated eight associations in AAs for the first time. Due to the difference of genetic variants between African Americans and the other races [23], it is interesting to check whether the associated variants reported in other races are associated with the same traits in AAs or not. When SNPs replicate across diverse populations, the gene's importance in the disease process is emphasized, and consistency of findings may indicate genes that are especially important for future functional validation. Importantly, the effects of eight variants in AAs were of the same directions as in the other reported races.

\section{Conclusions}

In this study, we leveraged the rich phenotype collection and the exome chip data in 7726 REGARDS AA participants, and examined the associations between 4956 GWAS catalog SNPs and 67 phenotypes. We validated 29 previous GWAS associations, of which eight associations were reported for the first time in AAs.

\section{Methods}

\section{Study population and design}

The REGARDS Study is a prospective, longitudinal population-based cohort study [8] of European American and African American adults aged 45 and older. Detailed description of the objectives and design of this study has been published [8]. The baseline telephone interview and separate in-home visit were conducted between 2003 to 2007 [24]. Baseline data collection resulted in a broad range of demographic, diet, and clinical information as well as banked biospecimens which were used to extract DNA and assess multiple clinical measurements [8]. Participants continue to be contacted every 6 months by telephone to identify stroke events and other incident outcomes [8]. The REGARDS study protocol was approved by the institutional review boards of each participating institution, and written informed consents were obtained from all participants. This current study examined phenotypes available in REGARDS participants to explore their association with exome-chip SNP genotypes. A total of 7726 self-reported African Americans with exome chip data were included in our study. The average age of participants was 64.6 years old (standard deviation $=9.0$ ), and $4770(61.7 \%)$ were female.

\section{SNP selection and genotyping}

Genotyping was conducted using the Infinium HumanExome-12v1-2_A from Illumina (San Diego, CA, USA). The Illumina exome chip provides genotype data on $>240,000$ putative functional variants selected based on over 12,000 individual exome and whole-genome sequences derived from individuals of European, African, Chinese, and Hispanic ancestry (http://genome.sph.umich.edu/wiki/Exome_Chip_Design). Raw genotyping data were called by GenomeStudio (version 2.0). The variant quality control included removing SNPs with call rate < 95\%, monoallelic SNPs, multiallelic SNPs, and SNPs that had mapping errors. After further removing first and second degree relatives, samples with technical issues, and samples with mismatched sex, 7726 samples were available for analysis. In total, 4956 autosomal SNPs with minor allele frequency $>0.05$ aligned to the GRCh37 reference sequence were matched to GWAS published SNPs catalog V1.0.1, which were reported to be associated with at least one trait with $P<1.0 \mathrm{E}-5$ (Additional file 1) $[7,25]$.

\section{Phenotypes}

Lists of phenotypes included in this study are shown in Table 2 and Table 3. The phenotypes included both baseline and incident events among the 7726 African Americans. Baseline information included medical history, personal history, demographic data, socioeconomic status, cognitive screening, laboratory assays, urine, height, weight, waist circumference, blood pressure, pulse, electrocardiography, and medications in the past 2 weeks [8]. Follow-up events included stroke, coronary heart disease (CHD), myocardial infarction, infection, sepsis, end-stage renal disease, and death. All the 
Table $\mathbf{2}$ List of binary phenotypes

\begin{tabular}{|c|c|c|c|c|c|}
\hline Short name & Category & Full description & $\begin{array}{l}\text { Number of } \\
\text { "yes" }\end{array}$ & $\begin{array}{l}\text { Number of } \\
\text { samples }\end{array}$ & $\begin{array}{l}\text { Frequency of } \\
\text { "yes" (\%) }\end{array}$ \\
\hline \multicolumn{6}{|l|}{ Prevalent Phenotypes } \\
\hline CogStatus $[26,27]$ & Aging & $\begin{array}{l}\text { Cognitive Status: Normal: defined as cogscore }>4 \text {, } \\
\text { Impaired: defined as cogscore }<=4\end{array}$ & 744 & 6195 & 12.01 \\
\hline Falls [28] & Aging & Self-reported fall in the past year & 1166 & 7704 & 15.13 \\
\hline Afib $[29,30]$ & CVD related & Atrial Fibrillation (self-report or ECG evidence) & 573 & 7526 & 7.61 \\
\hline CAD [31] & CVD related & $\begin{array}{l}\text { History of Heart Disease (self-reported MI, CABG, } \\
\text { bypass, angioplasty, or stenting OR evidence of } \\
\text { MI via ECG }\end{array}$ & 1186 & 7582 & 15.64 \\
\hline DVT [32] & CVD related & Self-reported deep vein thrombosis & 371 & 7699 & 4.82 \\
\hline Hypertension [33, 34] & CVD related & $\begin{array}{l}\text { Hypertensive if } \mathrm{SBP}>=140 \text { or } \mathrm{DBP}>=90 \text { or self- } \\
\text { reported current medication use to control blood } \\
\text { pressure }\end{array}$ & 5622 & 7714 & 72.88 \\
\hline Dyslipidemia [35] & CVD related & $\begin{array}{l}\text { Dyslipidemia: if TC }>=240 \text { or } \mathrm{LDL}>=160 \text { or } \mathrm{HDL} \\
<=40 \text { or on medication }\end{array}$ & 4171 & 7604 & 54.85 \\
\hline MI_SR [31] & CVD related & $\begin{array}{l}\text { History of Myocardial Infarction (MI) (self-reported } \\
\text { MI OR evidence of MI via ECG }\end{array}$ & 891 & 7588 & 11.74 \\
\hline PAD_amputation [36] & CVD related & History of leg amputation & 40 & 7725 & 0.52 \\
\hline PAD_surgery [36] & CVD related & Self-reported procedure to fix the arteries in legs & 162 & 7709 & 2.1 \\
\hline Stroke_SR $[37,38]$ & CVD related & Participant reported stroke at baseline & 597 & 7701 & 7.75 \\
\hline Stroke_Sympt $[39,40]$ & CVD related & Presence of stroke symptoms at baseline & 1632 & 7134 & 22.88 \\
\hline TIA $[29,37]$ & CVD related & $\begin{array}{l}\text { Participant reported Transient ischemic attack at } \\
\text { baseline }\end{array}$ & 257 & 7102 & 3.62 \\
\hline Diabetes [41] & Diabetes related & $\begin{array}{l}\text { Diabetic if fasting glucose }>=126 / \text { non-fasting } \\
\text { glucose }>=200 \text { or pills or insulin }\end{array}$ & 2335 & 7639 & 30.57 \\
\hline Cancer [42] & Other & Have you ever been diagnosed with cancer & 526 & 4895 & 10.75 \\
\hline Orthopnea [29] & Other & Require more than one pillow to sleep at night & 1076 & 7702 & 13.97 \\
\hline Dialysis [43] & Renal & Self-reported dialysis & 45 & 7670 & 0.59 \\
\hline KidneyFailure [43] & Renal & Self-reported kidney failure & 164 & 7670 & 2.14 \\
\hline \multicolumn{6}{|l|}{ Incident Phenotypes } \\
\hline CHD [44] & CVD related & Incidence of coronary heart disease until 2012 & 436 & 7726 & 5.64 \\
\hline MI [44] & CVD related & Incidence of myocardial infarction until 2012 & 284 & 7726 & 3.68 \\
\hline Stroke [45] & CVD related & Incidence of Stroke until 20,150,401 & 287 & 7726 & 3.71 \\
\hline Death [46] & Other & Incidence of Death until 20,150,401 & 1494 & 7726 & 19.34 \\
\hline Infection $[47,48]$ & Other & Incidence of infection & 548 & 7726 & 7.09 \\
\hline Sepsis $[47,48]$ & Other & Incidence of sepsis & 307 & 7726 & 3.97 \\
\hline Severe_sepsis $[47,48]$ & Other & Incidence of severe sepsis & 243 & 7726 & 3.15 \\
\hline ESRD [49] & Renal & Incidence of end stage renal disease until 2012 & 238 & 7726 & 3.08 \\
\hline
\end{tabular}

phenotypes were binary or continuous variables (See Tables 2-3). Totally, 26 binary and 41 continuous phenotypes were included for current study [26-68]. The binary variables follow a binomial distribution and their frequencies for each category were calculated. Most of the continuous variables followed normal distribution. For variables with large skewness or kurtosis, a logarithm or square root transformation was performed. Obvious outliers with values at more than 10 standard deviations away from the mean were redefined as missing.

\section{Statistical methods}

Single SNP linear or logistic regressions were performed by PLINK for continuous or binary phenotypes respectively using an additive genetic model. The top 10 principal components determined by EIGENSTRAT [69], age, and gender were used as covariates for all phenotypes. Additional covariates were used for cholesterol, high-density lipoprotein (HDL), low-density lipoprotein (LDL), triglyceride, glucose, and insulin. Those covariates included whether the participants were fasted under 
Table 3 The list of continuous phenotypes of this study

\begin{tabular}{|c|c|c|c|c|c|c|}
\hline Short name & Category & Full description & $\begin{array}{l}\text { Data } \\
\text { transformation }\end{array}$ & $\begin{array}{l}\text { Number of } \\
\text { samples }\end{array}$ & Mean & $\begin{array}{l}\text { Standard } \\
\text { deviation }\end{array}$ \\
\hline CogScore $[26,27]$ & Aging & Computed cognitive score & & 6195 & 5.45 & 0.85 \\
\hline Falls_number [28] & Aging & Number of times fallen in the past year & $\log 10(x+1)$ & 1182 & 0.42 & 0.2 \\
\hline MCS [50] & Aging & $\begin{array}{l}\text { The mental component of the short-form } \\
12 \text { health survey: Mental }\end{array}$ & & 7352 & 53.46 & 9.02 \\
\hline BMI [51] & Body size & Body Mass Index - kg/m2 & & 7657 & 30.84 & 6.73 \\
\hline Height [51] & Body size & Height & & 7702 & 66.4 & 3.88 \\
\hline Waist_cm [51] & Body size & Waist circumference $(\mathrm{cm})$ & & 7673 & 98.43 & 15.42 \\
\hline Weight_kg [51] & Body size & Weight (kg) & & 7694 & 87.99 & 20.54 \\
\hline ARICStroke & CVD related & $\begin{array}{l}\text { ARIC Stroke Risk Score: } 10 \text { Year Probability } \\
\text { of Ischemic Scroke (\%) }\end{array}$ & $\log 10$ & 6791 & 0.83 & 0.47 \\
\hline Cholest [52] & CVD related & Total Cholesterol (mg/dL) & & 7676 & 193.1 & 40.9 \\
\hline Crp [53] & CVD related & $C$ reactive protein (mg/L) & $\log 10$ & 7597 & 0.46 & 0.52 \\
\hline $\mathrm{DBP}[54,55]$ & CVD related & $\begin{array}{l}\text { Diastolic blood pressure - average of two } \\
\text { measures }(\mathrm{mmHg})\end{array}$ & & 7703 & 78.58 & 10.11 \\
\hline Fram_CHD_score [56] & CVD related & $\begin{array}{l}\text { Framingham CHD Hard Event Risk Score: } \\
\text { Risk of Coronary Death or Ml over } 10 \text { Years } \\
\text { (among those free of CHD at baseline) }\end{array}$ & $\log 10$ & 6381 & 0.86 & 0.4 \\
\hline Fram_stroke_score [57] & CVD related & $\begin{array}{l}\text { Framingham Stroke Risk Score: } 10 \text { Year } \\
\text { Probability of Stroke (\%) (among those } \\
\text { who self-reported never having a stroke } \\
\text { at baseline) }\end{array}$ & $\log 10$ & 6694 & 0.88 & 0.39 \\
\hline Hdl [52] & CVD related & HDL Cholesterol (mg/dL) & & 7622 & 53.46 & 15.9 \\
\hline Heartrate [58] & CVD related & Heart rate (beats per minute) & & 7627 & 68.48 & 11.95 \\
\hline Ideal7 [59] & CVD related & $\begin{array}{l}\text { American Heart Association Life simple seven, } \\
\text { total number of ideal for each of the seven }\end{array}$ & & 7726 & 2.12 & 1.08 \\
\hline Ldl [52] & CVD related & LDL Cholesterol (mg/dL) & & 7566 & 116.81 & 36.42 \\
\hline SBP $[54,55]$ & CVD related & $\begin{array}{l}\text { Systolic blood pressure - average of two } \\
\text { measures (mmHg) }\end{array}$ & & 7703 & 131.41 & 17.29 \\
\hline SLFS [60] & CVD related & Family risk score for stroke & & 4293 & -0.48 & 0.33 \\
\hline Stroke_Sym_Number $[39,40]$ & CVD related & Number of stroke symptoms & & 7134 & 0.39 & 0.87 \\
\hline Trigly [52] & CVD related & Triglycerides (mg/dL) & $\log 10$ & 7673 & 2.01 & 0.2 \\
\hline Glucose [41] & Diatetes related & $\begin{array}{l}\text { Glucose (mg/dL from labs formerly from } \\
\text { fromVermont) }\end{array}$ & sqrt & 7676 & 10.38 & 1.78 \\
\hline Insulin [41] & Diatetes related & Endogenous Insulin uU/mL & $\log 10$ & 5619 & 1.09 & 0.35 \\
\hline CESD [61] & Other & $\begin{array}{l}\text { Center for Epidemiologic Studies Depression } \\
\text { Scale }\end{array}$ & & 7670 & 1.39 & 2.21 \\
\hline DASH_Score [62] & Other & DASH style diet score & & 4592 & 23.11 & 4.25 \\
\hline Diet7 [59] & Other & Life simple seven, diet score & & 4592 & 1.17 & 0.37 \\
\hline Education [63] & Other & $\begin{array}{l}1=\text { 'Less than high school'; } 2=\text { 'High school } \\
\text { graduate'; } 3=\text { 'Some college'; } 4={ }^{\prime} \text { 'College } \\
\text { graduate and above'; missing }=-9 .\end{array}$ & & 7718 & 2.57 & 1.08 \\
\hline Income [63] & Other & Income & & 6763 & 5.7 & 2.13 \\
\hline MedDietScore [64] & Other & Mediterranean diet score & & 4483 & 4.43 & 1.64 \\
\hline PA7 [59] & Other & Life simple seven, physical activity & & 7618 & 1.89 & 0.79 \\
\hline PCS [50] & Other & PCS-12: SF-12 Physical & square root & 7325 & 4.55 & 1.1 \\
\hline Smoke7 & Other & Life simple seven, smoking & & 7726 & 2.63 & 0.76 \\
\hline TV [65] & Other & 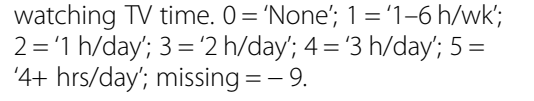 & & 5408 & 3.81 & 1.39 \\
\hline
\end{tabular}


Table 3 The list of continuous phenotypes of this study (Continued)

\begin{tabular}{|c|c|c|c|c|c|c|}
\hline Short name & Category & Full description & $\begin{array}{l}\text { Data } \\
\text { transformation }\end{array}$ & $\begin{array}{l}\text { Number of } \\
\text { samples }\end{array}$ & Mean & $\begin{array}{l}\text { Standard } \\
\text { deviation }\end{array}$ \\
\hline$\overline{A C R}[66]$ & Rental & Urinary Albumin/Creatinine ratio $(\mathrm{mg} / \mathrm{g})$ & $\log 10$ & 7421 & 1.09 & 0.62 \\
\hline Albumin_urine [66] & Rental & Urinary albumin (mg/L) & $\log 10$ & 7423 & 1.2 & 0.63 \\
\hline BUN [66] & Rental & Blood-urea-nitrogen (mg/dL) & $\log 10$ & 5472 & 1.18 & 0.16 \\
\hline Creatinine_serum [67] & Rental & IDMS Calibrated Creatinine (mg/dL) & $\log 10(x+1)$ & 7674 & 0.29 & 0.09 \\
\hline Creatinine_urine [66] & Rental & Urinary creatinine $(\mathrm{mg} / \mathrm{dL})$ & & 7437 & 152.1 & 84.59 \\
\hline Cysc [67] & Rental & Cystatin C (mg/L) & $\log 10$ & 7597 & 0 & 0.14 \\
\hline EGFR_CKDEPI [68] & Rental & estimated GFR from the CKD-Epi equation & & 7674 & 87.52 & 23.67 \\
\hline EGFR_MDRD [68] & Rental & $\begin{array}{l}\text { Glomerular Filtration Rate }(\mathrm{mL} / \mathrm{min} / 1.73 \\
\text { square meters) using IDMS calibrated } \\
\text { creatinine and MDRD equation }\end{array}$ & & 7674 & 89.36 & 27.15 \\
\hline
\end{tabular}

examination, whether they had self-reported diabetes and took insulin/glucose lowering pills, and whether they had self-reported dyslipidemia and took lipid lowering medication.

The threshold of significance level for PheWASs is not straightforward and multiple approaches have been used in other PheWAS studies [2-4]. The PAGE study used five population-based studies representing major racial/ ethnic groups, and their threshold is " $\mathrm{P}<0.01$ observed in two or more PAGE studies for the same SNP, phenotype class, and race/ethnicity, and consistent direction of effect" [2]. The Environmental Architecture for Genes Linked to Environment (EAGLE) study used similar threshold with an additional condition for allele frequency $>0.01$ and sample size $>200$ [4]. The Norfolk Island study performed a principal component analysis of phenotypes and used principal components as the final phenotypes. A $P$ value of $1.84 \mathrm{E}-7$ was considered the threshold for a significant association between a component and SNP [3]. In our study, the criteria for a significant association between a single SNP and a single phenotype with Bonferroni correction was defined as $\mathrm{P}$ value $=\frac{0.05}{4956 * 67}=1.5 \mathrm{E}-7$. In our study, significant genotype and phenotype associations involved 20 SNPs. Therefore, the significance threshold for a second trait of the pleiotropic effect is $P=0.05 /(67 * 20)=3.7 \mathrm{E}-5$.

\section{Additional files}

Additional file 1: List of 4956 SNPs included in the association tests. (XLS $3240 \mathrm{~kb}$ )

Additional file 2: Title: Matching of Regard significant associations with Published GWAS catalog (XLSX 85 kb)

Additional file 3: SNPs associated with multiple traits (XLSX $45 \mathrm{~kb}$ )

\section{Abbreviations}

GWAS: Genome-Wide Association Study; HDL: High-Density lipoprotein; LDL: Low-Density Lipoprotein; PAGE: Population Architecture using Genomics and Epidemiology; PheWAS: Phenome-Wide Association Study;
REGARDS: REasons for Geographic and Racial Differences in Stroke; SNP: single nucleotide polymorphism

\section{Acknowledgements}

The authors thank the other investigators, the staff, and the participants of the REGARDS study for their valuable contributions. A full list of participating REGARDS investigators and institutions can be found at http://www.regardsstudy.org.

\section{Funding}

The REasons for Geographic and Racial Differences in Stroke (REGARDS) cohort is supported by a cooperative agreement U01 NS041588 from the National Institute of Neurological Disorders and Stroke, National Institutes of Health, Department of Health and Human Service. The content is solely the responsibility of the authors and does not necessarily represent the official views of the National Institute of Neurological Disorders and Stroke or the National Institutes of Health. Representatives of the funding agency have been involved in the review of the manuscript but not directly involved in the collection, management, analysis or interpretation of the data. X.Z is supported by University of Alabama at Birmingham Statistical Genetics Post-Doctoral Training Grant (NIH T32HL072757). X.G. and D.Z. are partially supported by Agriculture and Food Research Initiative Competitive Grant no. 2015-67015-22975 from the USDA National Institute of Food and Agriculture (NIFA), and USDA Aquaculture Research Program Competitive Grant no. 2014-70007-22395. This work was also supported by 1RC4MD005964. Publication charges for this article have been funded by NIH R01HG010086.

\section{Availability of data and materials}

The datasets used and/or analysed during the current study are available from the corresponding author on reasonable request.

\section{About this supplement}

This article has been published as part of BMC Medical Genomics Volume 12 Supplement 1, 2019: Selected articles from the International Conference on Intelligent Biology and Medicine (ICIBM) 2018: medical genomics. The full contents of the supplement are available online at https:// bmcmedgenomics.biomedcentral.com/articles/supplements/volume-12supplement-1.

\section{Authors' contributions}

$\mathrm{MI}, \mathrm{DA}$, and $\mathrm{DZ}$ designed the study. $X Z, X G, V S$, and $D Z$ analyzed data. $X Z$, $X G, N C, M I$, and DZ wrote the manuscript. All the authors have participated in data interpretation, and read and approved the final manuscript.

\section{Ethics approval and consent to participate}

Our study has been approved by the appropriate internal review boards at the University of Texas Health Science Center at Houston and all other participating institutions, and it abides by the Declaration of Helsinki principles. 


\section{Consent for publication}

Not applicable.

\section{Competing interests}

The authors declare that they have no competing interests.

\section{Publisher's Note}

Springer Nature remains neutral with regard to jurisdictional claims in published maps and institutional affiliations.

\section{Author details}

'Department of Biostatistics, University of Alabama at Birmingham, Birmingham, AL 35233, USA. ${ }^{2}$ BGI-Shenzhen, Shenzhen 518083, China. ${ }^{3}$ School of Biomedical Informatics, The University of Texas Health Science Center at Houston, Houston, TX 77030, USA. ${ }^{4}$ Department of Epidemiology, University of Alabama at Birmingham, Birmingham, AL 35233, USA. ${ }^{5}$ Department of Medicine, University of Alabama at Birmingham, Birmingham, AL 35233, USA. 'Department of Emergency Medicine, University of Alabama at Birmingham, Birmingham, AL 35233, USA. ${ }^{7}$ Division of Biomedical Informatics and Personalized Medicine, Department of Medicine, University of Colorado Anschutz Medical Campus, Aurora, CO 80045, USA ${ }^{8}$ Department of Neurology and Rehabilitation Medicine, University of Cincinnati College of Medicine, Cincinnati, OH 45267, USA. ${ }^{9}$ Department of Psychiatry, Indiana University School of Medicine, Indianapolis, IN 46202, USA ${ }^{10}$ Division of General Internal Medicine, Weill Cornell Medical College, Cornell University, New York, NY 10065, USA. ${ }^{11}$ Department of Medicine and Pathology, Larner College of Medicine at the University of Vermont, Burlington, VT 05405, USA. ${ }^{12}$ Department of Neurology, University of Alabama at Birmingham, Birmingham, AL 35294, USA. ${ }^{13}$ Cardiovascular Research Institute, Department of Community Health and Preventive Medicine, Morehouse School of Medicine, Atlanta, GA 30310, USA. ${ }^{14}$ College of Public Health, University of Kentucky, Lexington, KY 40506, USA. ${ }^{15}$ School of Public Health, The University of Texas Health Science Center at Houston, Houston, TX 77030, USA

\section{Published: 31 January 2019}

\section{References}

1. Denny JC, Ritchie MD, Basford MA, Pulley JM, Bastarache L, Brown-Gentry K, Wang D, Masys DR, Roden DM, Crawford DC. PheWAS: demonstrating the feasibility of a phenome-wide scan to discover gene-disease associations. Bioinformatics. 2010;26(9):1205-10.

2. Pendergrass SA, Brown-Gentry K, Dudek S, Frase A, Torstenson ES, Goodloe $\mathrm{R}$, Ambite $\mathrm{J}$, Avery CL, Buyske S, Buzkova P, et al. Phenome-wide association study (PheWAS) for detection of pleiotropy within the population architecture using genomics and epidemiology (PAGE) network. PLoS Genet. 2013;9(1):e1003087.

3. Benton MC, Lea RA, Macartney-Coxson D, Hanna M, Eccles DA, Carless MA, Chambers GK, Bellis C, Goring HH, Curran JE, et al. A Phenomic scan of the Norfolk Island genetic isolate identifies a major pleiotropic effect locus associated with metabolic and renal disorder markers. PLoS Genet. 2015 11(10):e1005593.

4. Hall MA, Verma A, Brown-Gentry KD, Goodloe R, Boston J, Wilson S, McClellan B, Sutcliffe C, Dilks HH, Gillani NB, et al. Detection of pleiotropy through a phenome-wide association study (PheWAS) of epidemiologic data as part of the environmental architecture for genes linked to environment (EAGLE) study. PLoS Genet. 2014;10(12):e1004678.

5. Pendergrass SA, Brown-Gentry K, Dudek SM, Torstenson ES, Ambite JL, Avery CL, Buyske S, Cai C, Fesinmeyer MD, Haiman C, et al. The use of phenome-wide association studies (PheWAS) for exploration of novel genotype-phenotype relationships and pleiotropy discovery. Genet Epidemiol. 2011;35(5):410-22.

6. Namjou B, Marsolo K, Caroll RJ, Denny JC, Ritchie MD, Verma SS, Lingren T, Porollo A, Cobb BL, Perry C, et al. Phenome-wide association study (PheWAS) in EMR-linked pediatric cohorts, genetically links PLCL1 to speech language development and IL5-IL13 to eosinophilic esophagitis. Front Genet. 2014;5:401

7. Welter D, MacArthur J, Morales J, Burdett T, Hall P, Junkins H, Klemm A, Flicek P, Manolio T, Hindorff L, et al. The NHGRI GWAS catalog, a curated resource of SNP-trait associations. Nucleic Acids Res. 2014:42(Database issue):D1001-6.
8. Howard VJ, Cushman M, Pulley L, Gomez CR, Go RC, Prineas RJ, Graham A, Moy CS, Howard G. The reasons for geographic and racial differences in stroke study: objectives and design. Neuroepidemiology. 2005;25(3):135-43.

9. Smith EN, Chen W, Kähönen M, Kettunen J, Lehtimäki T, Peltonen L, Raitakari OT, Salem RM, Schork NJ, Shaw M. Longitudinal genome-wide association of cardiovascular disease risk factors in the Bogalusa heart study. PLoS Genet. 2010;6(9):e1001094.

10. Köttgen A, Pattaro C, Böger CA, Fuchsberger C, Olden M, Glazer NL, Parsa A, Gao X, Yang Q, Smith AV. New loci associated with kidney function and chronic kidney disease. Nat Genet. 2010;42(5):376-84.

11. Ng MC, Shriner D, Chen BH, Li J, Chen W-M, Guo X, Liu J, Bielinski SJ, Yanek LR, Nalls MA. Meta-analysis of genome-wide association studies in African Americans provides insights into the genetic architecture of type 2 diabetes. PLoS Genet. 2014;10(8):e1004517.

12. Shin S-Y, Fauman EB, Petersen A-K, Krumsiek J, Santos R, Huang J, Arnold M, Erte I, Forgetta $V$, Yang T-P. An atlas of genetic influences on human blood metabolites. Nat Genet. 2014;46(6):543-50.

13. Grallert H, Dupuis J, Bis JC, Dehghan A, Barbalic M, Baumert J, Lu C, Smith $\mathrm{NL}$, Uitterlinden AG, Roberts R. Eight genetic loci associated with variation in lipoprotein-associated phospholipase A2 mass and activity and coronary heart disease: meta-analysis of genome-wide association studies from five community-based studies. Eur Heart J. 2012;33(2):238-51.

14. Kettunen J, Tukiainen T, Sarin A-P, Ortega-Alonso A, Tikkanen E, Lyytikäinen L-P, Kangas AJ, Soininen P, Würtz P, Silander K. Genome-wide association study identifies multiple loci influencing human serum metabolite levels. Nat Genet. 2012:44(3):269-76.

15. Rasmussen-Torvik LJ, Pacheco JA, Wilke RA, Thompson WK, Ritchie MD, Kho AN, Muthalagu A, Hayes MG, Armstrong LL, Scheftner DA. High density GWAS for $L D L$ cholesterol in African Americans using electronic medical records reveals a strong protective variant in APOE. Clin Transl Sci. 2012:5(5):394-9.

16. Wu Y, Marvelle AF, Li J, Croteau-Chonka DC, Feranil AB, Kuzawa CW, Li Y, Adair LS, Mohlke KL. Genetic association with lipids in CLHNS: waist circumference modifies an APOA5 effect on triglyceride levels. J Lipid Res. 2013: jlr. P042077.

17. Chasman. Genetic determinants of statin-induced low-density lipoprotein cholesterol reduction: the justification for the use of statins in prevention: an intervention trial evaluating Rosuvastatin (JUPITER) trial (vol 5, pg 257, 2012). Circ Cardiovasc Genet. 2012:5(3):E27-7.

18. Willer CJ, Schmidt EM, Sengupta S, Peloso GM, Gustafsson S, Kanoni S, Ganna A, Chen J, Buchkovich ML, Mora S, et al. Discovery and refinement of loci associated with lipid levels. Nat Genet. 2013;45(11):1274-83.

19. Surakka I, Horikoshi M, Mägi R, Sarin A-P, Mahajan A, Lagou V, Marullo L, Ferreira T, Miraglio B, Timonen S. The impact of low-frequency and rare variants on lipid levels. Nat Genet. 2015;47(6):589-97.

20. Chasman DI, Pare G, Mora S, Hopewell JC, Peloso G, Clarke R, Cupples LA Hamsten A, Kathiresan S, Mälarstig A. Forty-three loci associated with plasma lipoprotein size, concentration, and cholesterol content in genomewide analysis. PLoS Genet. 2009;5(11):e1000730.

21. Lettre G, Palmer CD, Young T, Ejebe KG, Allayee H, Benjamin EJ, Bennett F, Bowden DW, Chakravarti A, Dreisbach A. Genome-wide association study of coronary heart disease and its risk factors in 8,090 African Americans: the NHLBI CARe project. PLoS Genet. 2011;7(2):e1001300.

22. Chu AY, Guilianini F, Grallert H, Dupuis J, Ballantyne CM, Barratt BJ, Nyberg F, Chasman DI, Ridker PM. Genome-Wide Association Study Evaluating LpPLA2 Mass and Activity at Baseline and Following Rosuvastatin Therapy. Circ Cardiovasc Genet. 2012; CIRCGENETICS. 112.963314.

23. Jorde LB, Wooding SP. Genetic variation, classification and'race'. Nat Genet. 2004;36:S28-33.

24. Tamura MK, Wadley V, Yaffe K, McClure LA, Howard G, Go R, Allman RM, Warnock DG, McClellan W. Kidney function and cognitive impairment in US adults: the Reasons for Geographic and Racial Differences in Stroke (REGARDS) Study. Am J Kidney Dis. 2008:52(2):227-234.

25. The NHGRI-EBI Catalog of published genome-wide association studies. [http://www.ebi.ac.uk/gwas] 2016.

26. Thacker EL, Gillett SR, Wadley VG, Unverzagt FW, Judd SE, McClure LA, Howard VJ, Cushman M. The American Heart Association Life's simple 7 and incident cognitive impairment: the REasons for geographic and racial differences in stroke (REGARDS) study. J Am Heart Assoc. 2014:3(3):e000635.

27. Wadley VG, Unverzagt FW, McGuire LC, Moy CS, Go R, Kissela B, McClure LA, Crowe M, Howard VJ, Howard G. Incident cognitive impairment is elevated in the stroke belt: the REGARDS study. Ann Neurol. 2011;70(2):229-36. 
28. O'Neal WT, Qureshi WT, Judd SE, Bowling CB, Howard VJ, Howard G, Soliman EZ. Effect of falls on frequency of atrial fibrillation and mortality risk (from the REasons for geographic and racial differences in stroke study). Am J Cardiol. 2015;116(8):1213-8.

29. Meschia JF, Merrill P, Soliman EZ, Howard VJ, Barrett KM, Zakai NA, Kleindorfer D, Safford M, Howard G. Racial disparities in awareness and treatment of atrial fibrillation: the REasons for geographic and racial differences in stroke (REGARDS) study. Stroke. 2010:41(4):581.

30. Prineas RJ, Soliman EZ, Howard G, Howard VJ, Cushman M, Zhang Z-M, Moy CS. The sensitivity of the method used to detect atrial fibrillation in population studies affects group-specific prevalence estimates: ethnic and regional distribution of atrial fibrillation in the REGARDS study. J Epidemiol. 2009:19(4):177-81.

31. Safford MM, Brown TM, Muntner PM, Durant RW, Glasser S, Halanych JH, Shikany JM, Prineas RJ, Samdarshi T, Bittner VA, et al. Association of race and sex with risk of incident acute coronary heart disease events. JAMA. 2012; 308(17):1768-74.

32. Zakai NA, McClure LA, Judd SE, Safford MM, Folsom AR, Lutsey PL, Cushman M. Racial and regional differences in venous thromboembolism in the United States in 3 cohorts. Circulation. 2014;129(14):1502.

33. Howard G, Prineas R, Moy C, Cushman M, Kellum M, Temple E, Graham A, Howard V. Racial and geographic differences in awareness, treatment, and control of hypertension: the REasons for geographic and racial differences in stroke study. Stroke. 2006;37(5):1171-8.

34. Safford MM, Halanych JH, Lewis CE, Levine D, Houser S, Howard G. Understanding racial disparities in hypertension control: intensity of hypertension medication treatment in the REGARDS study. Ethn Dis. 2007; 17(3):421-6

35. Zweifler RM, McClure LA, Howard VJ, Cushman M, Hovater MK, Safford MM, Howard G, Goff DC. Racial and geographic differences in prevalence, awareness, treatment and control of dyslipidemia: the reasons for geographic and racial differences in stroke (REGARDS) study. Neuroepidemiology. 2011;37(1):39-44.

36. Wang HE, Shapiro NI, Griffin R, Safford MM, Judd S, Howard G. Chronic medical conditions and risk of sepsis. PLoS One. 2012;7(10):e48307.

37. Judd SE, Kleindorfer DO, McClure LA, Rhodes JD, Howard G, Cushman M, Howard VJ. Self-report of stroke, transient ischemic attack, or stroke symptoms and risk of future stroke in the REasons for geographic and racial differences in stroke (REGARDS) study. Stroke. 2013;44(1):55.

38. Howard G, McClure LA, Moy CS, Howard VJ, Judd SE, Yuan Y, Long DL, Muntner P, Safford MM, Kleindorfer DO. Self-reported stroke risk stratification: reasons for geographic and racial differences in stroke study. Stroke. 2017:48(7):1737-43.

39. Gao L, Meschia JF, Judd SE, Muntner P, McClure LA, Howard VJ, Rhodes JD, Cushman M, Safford MM, Soliman EZ, et al. What stroke symptoms tell us: association of risk factors and individual stroke symptoms in the REasons for geographic and racial differences in stroke (REGARDS) study. J Stroke Cerebrovasc Dis. 2012;21(5):411-6.

40. Howard G, Safford MM, Meschia JF, Moy CS, Howard VJ, Pulley L, Gomez CR, Crowther M. Stroke symptoms in individuals reporting no prior stroke or transient ischemic attack are associated with a decrease in indices of mental and physical functioning. Stroke. 2007;38(9):2446-52.

41. Carson AP, Muntner P, Kissela BM, Kleindorfer DO, Howard VJ, Meschia JF, Williams LS, Prineas RJ, Howard G, Safford MM. Association of prediabetes and diabetes with stroke symptoms: the REasons for geographic and racial differences in stroke (REGARDS) study. Diabetes Care. 2012;35(9):112140.

42. O'Neal WT, Lakoski SG, Qureshi W, Judd SE, Howard G, Howard VJ, Cushman M, Soliman EZ. Relation between cancer and atrial fibrillation (from the REasons for geographic and racial differences in stroke study). Am J Cardiol. 2015;115(8):1090-4.

43. McClellan WM, Warnock DG, Judd S, Muntner P, Patzer RE, Bradbury BD, McClure LA, Newsome BB, Howard G. Association of family history of ESRD, prevalent albuminuria, and reduced GFR with incident ESRD. Am J Kidney Dis. 2012;59(1):25-31.

44. Moise N, Khodneva Y, Richman J, Shimbo D, Kronish I, Safford MM. Elucidating the association between depressive symptoms, coronary heart disease, and stroke in black and white adults: the REasons for geographic and racial differences in stroke (REGARDS) study. J Am Heart Assoc. 2016;5(8):e003767.

45. Howard VJ, McClure LA, Kleindorfer DO, Cunningham SA, Thrift AG, Diez Roux AV, Howard G. Neighborhood socioeconomic index and stroke incidence in a national cohort of blacks and whites. Neurology. 2016;87(22):10.1212.
46. Whalen KA, Judd S, McCullough ML, Flanders WD, Hartman TJ, Bostick RM Paleolithic and Mediterranean diet pattern scores are inversely associated with all-cause and cause-specific mortality in adults. J Nutr. 2017:1217-26.

47. Chaudhary NS, Donnelly JP, Moore JX, Baddley JW, Safford MM, Wang HE. Association of baseline steroid use with long-term rates of infection and sepsis in the REGARDS cohort. Crit Care. 2017;21(1):185.

48. Wang HE, Addis DR, Donnelly JP, Shapiro NI, Griffin RL, Safford MM, Baddley JW. Discharge diagnoses versus medical record review in the identification of community-acquired sepsis. Crit Care. 2015;19:42.

49. O'Neal WT, Tanner RM, Efird JT, Baber U, Alonso A, Howard VJ, Howard G, Muntner P, Soliman EZ. Atrial fibrillation and incident end-stage renal disease: the REasons for geographic and racial differences in stroke (REGARDS) study. Int J Cardiol. 2015;185:219-23.

50. Haley WE, Roth DL, Kissela B, Perkins M, Howard G. Quality of life after stroke: a prospective longitudinal study. Qual Life Res. 2011;20(6):799-806.

51. Kramer H, Gutiérrez OM, Judd SE, Muntner P, Warnock DG, Tanner RM, Panwar B, Shoham DA, McClellan W. Waist circumference, body mass index, and ESRD in the REGARDS (reasons for geographic and racial differences in stroke) study. Am J Kidney Dis. 2016;67(1):62-9.

52. Booth JN, Colantonio LD, Howard G, Safford MM, Banach M, Reynolds K, Cushman M, Muntner P. Healthy lifestyle factors and incident heart disease and mortality in candidates for primary prevention with statin therapy. Int J Cardiol. 2016;207:196-202.

53. Dawood FZ, Judd S, Howard VJ, Limdi NA, Meschia JF, Cushman M, Howard G, Herrington DM, Soliman EZ. High-sensitivity C-reactive protein and risk of stroke in atrial fibrillation (from the reasons for geographic and racial differences in stroke study). Am J Cardiol. 2016;118(12):1826-30.

54. Howard G, Lackland DT, Kleindorfer DO, Kissela BM, Moy CS, Judd SE, Safford MM, Cushman M, Glasser SP, Howard VJ. Racial differences in the impact of elevated systolic blood pressure on stroke risk. JAMA Intern Med. 2013;173(1):46-51

55. Glasser SP, Halberg DL, Sands C, Gamboa CM, Muntner P, Safford M. Is pulse pressure an independent risk factor for incident acute coronary heart disease events? The REGARDS study. Am J Hypertens. 2014;27(4):555-63.

56. Safford MM, Gamboa CM, Durant RW, Brown TM, Glasser SP, Shikany JM, Zweifler RM, Howard G, Muntner P. Race-sex differences in the management of hyperlipidemia: the REasons for geographic and racial differences in stroke study. Am J Prev Med. 2015;48(5):520-7.

57. McClure LA, Kleindorfer DO, Kissela BM, Cushman M, Soliman EZ, Howard G. Assessing the performance of the Framingham stroke risk score in the reasons for geographic and racial differences in stroke cohort. Stroke. 2014; 45(6): 1716.

58. O'Neal WT, Qureshi WT, Judd SE, Meschia JF, Howard VJ, Howard G, Soliman EZ. Heart rate and ischemic stroke: the REasons for geographic and racial differences in stroke (REGARDS) study. Int J Stroke. 2015;10(8):1229-35.

59. Kulshreshtha A, Vaccarino V, Judd SE, Howard VJ, McClellan WM, Muntner $P$, Hong Y, Safford MM, Goyal A, Cushman M: Life's Simple 7 and risk of incident stroke: the reasons for geographic and racial differences in stroke study. Stroke 2013, 44(7): doi: https://doi.org/10.1161/STROKEAHA.111.000352.

60. Kennedy RE, Howard G, Go RC, Rothwell PM, Tiwari HK, Feng R, McClure LA, Prineas RJ, Banerjee A, Arnett DK. Association between family risk of stroke and myocardial infarction with prevalent risk factors and coexisting diseases. Stroke. 2012:43(4):974

61. Kronish IM, Carson AP, Davidson KW, Muntner P, Safford MM. Depressive symptoms and cardiovascular health by the American Heart Association's definition in the reasons for geographic and racial differences in stroke (REGARDS) study. PLoS One. 2012;7(12):e52771.

62. Shimbo D, Levitan EB, Booth JN, Calhoun DA, Judd SE, Lackland DT, Safford MM, Oparil S, Muntner P. The contributions of unhealthy lifestyle factors to apparent resistant hypertension: findings from the Reasons for Geographic And Racial Differences in Stroke (REGARDS) study. J Hypertens. 2013;31(2). https://doi.org/10.1097/HJH.0b013e32835b6be7.

63. Lewis MW, Khodneva Y, Redmond N, Durant RW, Judd SE, Wilkinson LL, Howard VJ, Safford MM. The impact of the combination of income and education on the incidence of coronary heart disease in the prospective reasons for geographic and racial differences in stroke (REGARDS) cohort study. BMC Public Health. 2015;15:1312.

64. Tsivgoulis G, Judd S, Letter AJ, Alexandrov AV, Howard G, Nahab F, Unverzagt FW, Moy C, Howard VJ, Kissela B, et al. Adherence to a Mediterranean diet and risk of incident cognitive impairment. Neurology. 2013;80(18):1684-92 
65. McDonnell MN, Hillier SL, Judd SE, Yuan Y, Hooker SP, Howard VJ. Association between television viewing time and risk of incident stroke in a general population: results from the REGARDS study. Prev Med. 2016;87:1-5.

66. Warnock DG, Muntner P, McCullough PA, Zhang X, McClure LA, Zakai N,

Cushman M, Newsome BB, Kewalramani R, Steffes MW, et al. Kidney function, albuminuria, and all-cause mortality in the REGARDS (reasons for geographic and racial differences in stroke) study. Am J Kidney Dis. 2010; 56(5):861-71.

67. Colantonio LD, Tanner RM, Warnock DG, Gutiérrez OM, Judd S, Muntner P, Bowling CB. The role of cystatin-C in the confirmation of reduced glomerular filtration rate among the oldest old. Arch Med Sci. 2016;12(1):55.

68. Matsushita K, Mahmoodi BK, Woodward M, Emberson JR, Jafar TH, Jee SH, Polkinghorne KR, Shankar A, Smith DH, Tonelli M, et al. Comparison of risk prediction using the CKD-EPI equation and the MDRD study equation for estimated glomerular filtration rate. JAMA. 2012;307(18):1941-51.

69. Price AL, Patterson NJ, Plenge RM, Weinblatt ME, Shadick NA, Reich D. Principal components analysis corrects for stratification in genome-wide association studies. Nat Genet. 2006;38(8):904-9.

Ready to submit your research? Choose BMC and benefit from:

- fast, convenient online submission

- thorough peer review by experienced researchers in your field

- rapid publication on acceptance

- support for research data, including large and complex data types

- gold Open Access which fosters wider collaboration and increased citations

- maximum visibility for your research: over $100 \mathrm{M}$ website views per year

At $\mathrm{BMC}$, research is always in progress.

Learn more biomedcentral.com/submissions 